[이 100-РТЧЧЧ

MLWH HAPOДHOI

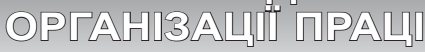

\section{Роман ЄДЕЛЄВ}

\section{Міжнародна організація праці: 100 років розвитку міжнародного права}

\begin{abstract}
Стаття присвячена сторіччю МОП та досліджує аспекти, які визначають ефективність МОП: 1) робота на основі принципу трипартизму; 2) особливий контрольний механізм із оцінки рівня дотримання державами міжнародних трудових стандартів та надання їм рекомендацій; 3) механізм подання компетентним органам держави текстів нових, тобто щойно прийнятих, міжнародних трудових стандартів для вирішення питання можливості їхньої ратифікації; 4) механізм оцінки стандартів на актуальність; 5) механізм співробітництва між міжнародними організаціями у сфері становлення міжнародних трудових стандартів; 6) механізм співпраці МОП та держав-членів у формі програм гідної праці для країни. Саме ці рушійні сили названі найбільшою окрасою МОП та її «подарунком» міжнародному праву.

Ключові слова: Міжнародна організація праці, міжнародний трудовий стандарт, ефективність міжнародного права, трипартизм, механізм роботи
\end{abstract} міжнародної організації.

The article focuses on the ILO's centennial and explores aspects that determine its effectiveness: 1) activity based on the tripartism principle; 2) specific control mechanism for assessing and providing recommendations to Member States on compliance with international labour standards; 3) submitting mechanism to the competent State's authorities of the newly adopted international labour standards texts in order to study the possibility of its ratification; 4) standards review mechanism; 5) cooperation mechanism between international organizations in the field of international labour standards; 6) cooperation mechanism between the ILO and its Member States in the form of decent work country programmes. These driving forces were considered as the ILO's greatest jewels and its "gift" to international law.

Keywords: International Labour Organization, international labour standard, effectiveness of international law, tripartism, mechanism of work of international organization.

Перші пропозиції міжнародного регулювання питань праці висловлювалися ще у XIX ст. Перші конкретні кроки і спроби здійснення такого регулювання були зроблені в останнє десятиліття XIX ст., коли були проведені конгреси з питань трудового регулювання. Однак про реальне міжнародно-правове регулювання праці ми можемо говорити лише з перших років XX ст. Найважливішим моментом стало створення Міжнародної асоціації з питань трудового законодавства, неурядової організації, до складу якої входили незалежні експерти з трудового права. Ї̈̈ робота сприяла і забезпечила успішне проведення міжнародних конференцій з питань праці, результатом яких стали перші міжнародно-правові акти у сфері праці. Конвенції, прийняті в 1906 році, отримали достатньо високий для свого часу рівень ратифікацій, а проекти конвенцій, розроблені в 1913 році, мали високий рівень підтримки на момент розробки. Саме це дозволяє стверджувати, що асоціацією була проведена успішна робота, яка проклала шлях до створення Міжнародної організації праці (далі МОП) і заклала основи вже ії діяльності, навіть незважаючи на свій неофіційний характер [1, с. 9].

Але очевидно, що галузь міжнародного трудового права нерозривно пов'язана з МОП. На засіданні Паризької мирної конференції (11.04.1919 р.) був затверджений Статут МОП, а 28.04.1919 p. була затверджена декларація принципів роботи МОП. Ці документи увійшли в якості частини XIII

УДК 341.162/331.91

() P. Єделєв, 2019
ЄДЕЛєВ Роман Сергійович

кандидат юридичних наук, асистент кафедри міжнародного права Інституту міжнародних відносин Київського національного університету імені Тараса Шевченка 
в Версальський мирний договір. 29.10.1919 р. у Вашингтоні, округ Колумбія, відкрила свою роботу перша Міжнародна конференція праці (далі МКП), яка протягом досить тривалого періоду іменувалася як «Генеральна конференція». Ця дата вважається днем народження МОП.

За сто років своєї діяльності МОП вдалося досягти надзвичайних результатів: 187 держав-членів, 190 прийнятих конвенцій та протоколів, остання на даний момент 3 яких прийнята у 2019 році, 206 рекомендацій, які хоч і не мають нормативної обов' язковості, але сприяють належному здійсненню міжнародно-правових зобов'язань, що містяться у конвенціях, та значний досвід у просуванні, сприянні дотриманню та загалом забезпеченні ефективності міжнародних трудових стандартів.

Загалом, вітання $з$ ювілеєм повинні містити побажання успіхів у подальшій роботі. Але у цій статті, безпосередньо присвяченій сторіччю МОП, хотілося б дослідити аспекти, які, на мою думку, визначають ефективність МОП. Саме ці рушійні сили є найбільшою окрасою МОП та, так би мовити, іiі «подарунком» міжнародному праву. Деякі з цих аспектів є унікальними і характерними лише для МОП, деякі - були започатковані в МОП і зараз успішно використовуються більшістю інших міжнародних організацій, окремі - є звичними для права та діяльності міжнародних організацій. Але кожний з цих аспектів у рамках МОП має свої особливості, що саме у сукупності дозволяє їм забезпечувати високий рівень ефективності.

Перелік згаданих вище аспектів не є вичерпним. Але для цілей цієї статті, далі будуть досліджені такі аспекти діяльності МОП, що можуть слугувати ії визначальними характеристиками і запозичені для роботи інших міжнародних організацій: 1) робота на основі принципу трипартизму; 2) особливий контрольний механізм із оцінки рівня дотримання державами міжнародних трудових стандартів та надання їм рекомендацій; 3) механізм подання компетентним органам держави текстів нових, тобто щойно прийнятих, міжнародних трудових стандартів для вирішення питання можливості їхньої ратифікації; 4) механізм оцінки стандартів на актуальність; 5) механізм співробітництва між міжнародними організаціями у сфері становлення міжнародних трудових стандартів; 6) механізм співпраці МОП та держав-членів у формі програм гідної праці для країни.

\section{Робота на основі принципу трипартизму}

Статут МОП не дає прямого визначення трипартизму. Таке упущення може здивувати, оскільки в доктрині існує одностайність, що цей принцип є основним стовпом Міжнародної організації праці та ії основною характеристикою [2, с. 123]. За відсутності визначення, Статут містить положення, що, безумовно, служать основою трипартизму. Відповідно до п. 1 ст. 3 Статуту, МКП має скликатися час від часу кожного разу, коли цього потребують обставини, але не рідше, ніж один раз на рік [3, с. 6]. В ній повинні брати участь по чотири представники від кожного члена МОП, з яких двоє є урядовими делегатами, а двоє інших представляють відповідно: один - роботодавців, а інший - працівників.

Хоча сесії МКП, в яких беруть участь тристоронні представники держав-членів, щорічно проводяться протягом кількох тижнів, ії рішення як вищого органу МОП, який приймає не тільки міжнародні трудові норми та всі найважливіші рішення, які стосуються програм та пріоритетів МОП, але також і рішення, що зачіпають склад інших органів МОП, які відповідають за реалізацію цих програм та завдань, зачіпають весь спектр діяльності МОП [4, с. 3]. Делегати від роботодавців і працівників інтенсивно залучені, майже на рівних з урядовими делегатами, на різних стадіях обговорення зазначених вище питань на МКП і, наприклад, можуть пропонувати текст, вносити зміни і робити зауваження до міжнародних стандартів праці [5, с. 696]. МКП також може слугувати форумом для налагодження співробітництва між професійними організаціями різних країн. У зв'язку 3 цим, нескладно уявити собі важливість процедури, відповідно до якої визначається чи дійсно неурядові делегати, призначені членом МОП, представляють інтереси підприємців та працівників.

Так, Статут передбачає два механізми, що забезпечують збалансоване врахування інтересів всіх груп, що складають делегацію кожної держави-члена на МКП у тому складі, як це передбачено п. 1 ст. 3 Статуту. Відповідно до першого механізму, передбаченому в п. 2 ст. 4 Статуту, у випадку призначення до складу делегації на МКП лише одного неурядового делегата (від роботодавців або працівників) замість передбачених двох делегатів, цей делегат позбавляється права голосу на МКП та в ії комітетах [3, с. 8]. Другий механізм - це процедура визнання недійсними повноважень, передбачена у п. 9 ст. 3 Статуту. Повноваження делегатів та їх радників повинні бути перевірені МКП, яка може більшістю у дві третини голосів, поданих присутніми делегатами, відмовитися допустити якогось делегата або радника, якщо вважатиме, що правила призначення, визначені у ст. 3, не були дотримані. Відповідно до положень п. 3 ст. 4 Статуту, в разі визнання повноважень якого-небудь неурядового делегата недійсними, другий неурядовий делегат також втрачає право участі у голосуванні на МКП та в ії комітетах [3, с. 8]. Обидва ці механізми покликані гарантувати, що відсутність одного неурядового делегата не підриватиме балансу інтересів. 
На відміну від першого механізму, який застосовується автоматично, другий потребує рішення МКП, яке приймається за пропозицією Комітету з перевірки повноважень (далі КПП) або одного 3 його трьох членів. Історія КПП є однією з найбільш багатих у МОП [4, с. 2]. Заснований на першій сесії МКП у 1919 р. 3 метою виконання функцій, покладених на неї відповідно до п. 9 ст. 3 Статуту, КПП згодом став одним з постійно діючих комітетів МКП та покликаний займатися інтерпретацією змісту та умов застосування принципу, передбаченого в п. 5 ст. 3 Статуту, який регламентує склад делегацій, що направляються на МКП [6, с. 55].

Визнання повноважень недійсними, безумовно, дозволяє уникнути того, щоб у МКП брали участь представники, які не мають достатньої кваліфікації або відповідних повноважень, аби представляти інтереси, відповідно, працівників або роботодавців. Проте така практика позбавляє іншого неурядового делегата права голосу, і насправді саме він, а не відповідний уряд, страждає від наслідків відсутності в уряду прагнення щодо дотримання власних зобов'язань [7, с. 185]. Це, крім іншого, призводить до того, що в ході прийняття рішень МКП та чи інша з двох неурядових груп виявляється позбавленої певного числа голосів, при цьому голоси двох інших груп не врівноважуються, на відміну від того, що відбувається у комітетах МКП або в межах Адміністративної ради (далі - АР). Та ж проблема виникає і в разі відсутності на МКП неурядових делегатів через нестачу у них фінансових коштів для участі в роботі сесії МКП.

Першим кроком у розробці міжнародного стандарту праці є визначення проблемного питання, що вимагає регулювання, та включення його АР до порядку денного МКП. Далі визначається, що МКП розглядатиме це питання шляхом здійснення процедури двократного обговорення і результатом повинно стати створення нового міжнародного стандарту праці.

Після цього, МБП, відповідно до Регламенту МКП, готує доповідь про законодавство та практику в різних країнах, а також перелік питань. Ця доповідь і перелік питань містять прохання до урядів про проведення консультацій з найбільш представницькими організаціями роботодавців і працівників до складання остаточного варіанта відповідей. Для того щоб відповіді урядів знайшли відображення у доповіді, вони повинні надійти в МБП не пізніше ніж за 11 місяців до відповідної сесії. Після того як були отримані відповіді держав, МБП готує новий проект доповіді, який включає коментарі держав, коментарі МБП та пропоновані висновки, і передає його державам. Ці дві доповіді складають основу для першого обговорення.

Перше обговорення державами-членами МОП, зазвичай, закінчується прийняттям резолюції наступного змісту: «[МКП] постановляє включити до порядку денного своєї чергової сесії пункт під назвою «...», для другого обговорення з метою прийняття всеосяжної норми (конвенції, доповненої рекомендацією)». 3 цією метою МБП готується нова доповідь, яка містить пропоновані Конвенцію та Рекомендацію, що були розроблені на основі висновків сесії МКП. Урядам пропонується провести консультації з організаціями роботодавців та працівників, а також направити свої пропозиції або зауваження до МБП. Крім того, уряди мали проінформувати МБП про те, чи вважають вони запропоновані тексти прийнятними для основи переговорів на наступній сесії МКП.

За результатами наданих державами коментарів, МБП готується нова доповідь, яка складалася 3 двох частин: перша частина містить отримані коментарі стосовно конвенції та рекомендації, а друга частина - пропоновані тексти конвенції та рекомендації. Ця доповідь має бути винесена на обговорення чергової сесії МКП.

Під час наступної сесії МКП це питання обговорюватиметься у спеціально створеному Комітеті конференції. Наприклад, Конвенція № 189 про гідну працю домашніх працівників, прийнята 16 червня 2011 р., обговорювалася в Комітеті гідної праці домашніх працівників, структура якого засновувалась на принципі трипартизму. Комітет складався з 209 членів: 102 представники від урядів держав, 35 представників від організацій роботодавців та 72 представники від організацій працівників. Для досягнення рівної ваги голосів, кожен представник уряду мав 420 голосів, кожен представник від організації роботодавців - 1224 голоси, а кожен представник від організації працівників - 595 голосів $[8$, с. 1]. Після обговорення і голосування у комітеті, текст конвенції та рекомендації має бути передано на голосування і прийняття МКП.

Таким чином, для створення нового міжнародного стандарту праці витрачається близько трьох років. За цей час МБП готується 4 доповіді, уряди, після консультацій з організаціями роботодавців та працівників, два рази надають свої коментарі до доповідей МБП, відбувається два обговорення у рамках відповідного комітету МКП. Організація роботи саме таким чином дозволяє отримати достатньо високий рівень підтримки під час остаточного голосування на МКП. Загалом же, трипартизм дозволяє врахувати позиції та пропозиції всіх належних сторін ще на етапі напрацювання тексту конвенції та супровідної рекомендації, а не на етапі підготовки до ратифікації або взагалі після неї. Результатом цього є зростання ефективності міжнародно-правового регулювання, що здійснюється МОП. 
Особливий контрольний механізм із оцінки рівня дотримання державами міжнародних трудових стандартів та надання їм рекомендацій

Міжнародні організації створюються державами не лише з метою прийняття нових міжнародно-правових норм. Контрольний механізм, який може створюватися в рамках таких організацій, є не менш важливим. Звичайно, кожний окремий міжнародний договір може передбачати власний контрольний механізм, але це буде призводити до складнощів належного забезпечення виконання передбачених зобов' язань.

Для здійснення моніторингу прогресу держав-членів у сфері застосування міжнародних трудових норм, МОП розробила контрольні механізми, які мають унікальний характер на міжнародному рівні. На думку Н. Вальтікоса, система контролю за дотриманням актів МОП є більш досконалою, ніж аналогічні контрольні механізми в інших міжнародних організаціях [9, с. 143]. Як зазначає В.Г. Стаценко, в останні роки нормотворчість, як напрямок діяльності МОП, поступово поступається місцем контролю за застосуванням ¥ї конвенцій і рекомендацій [10, с. 18].

Водночас контрольний механізм МОП пов'язаний не тільки з дотриманням і належною реалізацією міжнародно-правових норм. МОП також здійснює контроль за належним представництвом інтересів працівників та роботодавців на МКП, зважаючи на ї̈ особливу важливість (МКП приймає не тільки міжнародні трудові норми та всі найважливіші рішення, які стосуються програм та пріоритетів МОП, але також і рішення, що зачіпають склад інших органів МОП, які відповідають за реалізацію цих програм та завдань).

Міжнародний трудовий стандарт, який складається як з юридично-обов' язкової конвенції, так і з супровідної рекомендації, сьогодні стає не тільки зобов'язанням, а ще й орієнтиром до належного реформування трудового права держав-членів МОП. Зважаючи на те, що, відповідно до преамбули Статуту МОП, відмова якої-небудь країни створити працюючим особам людські умови праці є перешкодою для інших народів, які бажають поліпшити умови праці у своїх країнах, держави-члени МОП зацікавлені у реформуванні внутрішнього трудового права інших держав-членів. Механізм нагляду як раз може сприяти такому реформуванню, а не лише здійснювати функції контролю і покарання.

Система нагляду МОП складається з трьох частин: 1) процедур, передбачених у Статуті МОП; 2) спеціальних процедур, розроблених у співпраці з $\mathrm{OOH}$, для розслідування можливих порушень свободи об'єднань; 3) процедур постійного нагляду [11, с. 18]. Відповідно до ст. 22 Статуту МОП, кожен з членів МОП зобов'язується представляти щорічні доповіді МБП щодо вжитих ним заходів для застосування конвенцій, до яких він приєднався. Однак Статут МОП не містить положень, яким чином ст. 22 має бути реалізована.

Ключова роль у регулярному контролі належить Комітету експертів із застосування конвенцій і рекомендацій МОП (далі - КЕЗКР). КЕЗКР складається з 20 національно і всесвітньо відомих експертів у сфері трудового права, які пропонуються Генеральним директором МОП і призначаються Радою керуючих МОП на поновлюваний період в три роки. Члени КЕЗКР призначаються в особистій якості на основі їх неупередженості, технічної компетентності та незалежності статусу. Члени представляють різні регіони світу з тим, щоб дати КЕЗКР можливість мати у своєму розпорядженні досвід різних правових, економічних і соціальних систем [12, с. 209]. КЕЗКР покликаний розглядати: i) щорічні доповіді, відповідно до ст. 22 Статуту про заходи, які провадять члени Організації стосовно надання сили положенням конвенції, до яких вони приєдналися, а також інформацію, яка надається членами Організації стосовно результатів проведених інспекцій; ii) інформацію та доповіді, стосовно конвенцій та рекомендацій, які надаються членами Організації відповідно до ст. 19 Статуту; iii) інформацію та доповіді про заходи, які вживаються членами Організації згідно зі ст. 35 Статуту.

Документація, наявна у розпорядженні КЕЗКР, включає інформацію, яка надходить від урядів у ïx доповідях, або яка направляється ними ККЗКР; відповідні законодавчі акти, колективні договори та судові рішення; інформацію, яка направляється державами-членами про результати проведення інспекцій; коментарі організацій роботодавців та працівників; доповіді інших органів МОП та доповіді, стосовно діяльності у сфері технічного співробітництва [13, с. 38].

За підсумками своєї роботи КЕЗКР видає щорічну доповідь. Доповідь видається у двох томах і містить такі частини (частини I і II складають перший том, а частина III - другий):

Частина І містить загальну доповідь (огляд роботи КЕЗКР, також звертається увага АР МБП, МКП та держав-членів на питання, що становлять загальний інтерес, або на особливі труднощі);

Частина II містить таку інформацію:

- зауваження на адресу конкретних держав-членів щодо: і) застосування в них ратифікованих конвенцій; іi) застосування конвенцій на територіях за межами метрополії, щодо міжнародних від- 
носин, яких держави-члени несуть відповідальність; іiі) представлення конвенцій та рекомендацій на розгляд національних компетентних органів;

- прямі запити: інші індивідуальні коментарі, які направляються на адресу урядів Генеральним директором МБП від імені КЕЗКР;

- випадки висловлення подяки: коли уряд направив МБП вичерпну відповідь на прямий запит про подальшу інформацію, та цим вичерпав необхідність у нових коментарях;

Частина III містить загальний огляд національного законодавства та практики стосовно актів, за якими були підготовані доповіді, за нератифікованими конвенціями, відповідно до ст. 19 Статуту.

Процес імплементації міжнародно-правових зобов'язань у трудовій сфері є вкрай складним і потребує значних зусиль. Хоча проблемні моменти імплементації положень конвенцій МОП і залишаються, проте процес імплементації, який відповідно призводить до процесу реформування, відбувається постійно. Вплив діяльності КЕЗКР на реформування трудового права здійснюється шляхом представлення державам-учасницям МОП зауважень, в тому числі у формі рекомендацій, щодо застосування в них ратифікованих конвенцій. КЕЗКР відіграє важливу роль у цьому процесі, навіть маючи доволі м'які у юридичному сенсі механізми впливу, оскільки держави, в тому числі й Україна, дослуховуються до рекомендацій, які ним надаються.

Механізм подання компетентним органам держави текстів нових, тобто щойно прийнятих, міжнародних трудових стандартів для вирішення питання можливості їхньої ратифікації

Ще до початку першої стадії імплементації, тобто стадії вираження державою згоди на обов'язковість для неї договору, зовнішні чинники - зміст міжнародних норм та їх соціальні особливості - визначають принципову позицію держави по відношенню до них. Приймаючи рішення про доцільність чи недоцільність прийняття на себе зобов'язань за договором, вона неодмінно враховує як ступінь відповідності міжнародної норми до свого законодавства, так і існуючу національну процедуру трансформації й виконання міжнародних договорів.

Коли мова йде про документи, ухвалені в МОП, на позицію держави на цьому етапі впливає такий специфічний зовнішній фактор, як обов'язок подання міжнародних конвенцій та рекомендацій МОП на розгляд компетентних державних властей - процедура, що дозволяє залучити увагу до міжнародного документа різних суспільно-політичних сил, які здатні в тій чи іншій мірі вплинути на остаточне рішення держави [14, с. 47].

Всі держави-члени МОП зобов'язані подавати конвенції та рекомендації компетентним національним органам влади. Відповідно до п. 5 ст. 19 Статуту МОП, у відношенні конвенції повинні бути здійснені наступні дії: а) конвенція розсилається всім членам МОП для ратифікації; b) кожен член МОП зобов' язується протягом року з моменту закриття сесії МКП (або, якщо це неможливо, зважаючи на виняткові обставини, якнайшвидше, наскільки це практично можливо, але не пізніше 18 місяців 3 моменту закриття сесії МКП) подати конвенцію на розгляд органу або органів влади, до сфери компетенції яких входить це питання, для прийняття відповідного закону або для вжиття заходів іншого порядку; с) члени МОП інформують Генерального директора МБП про заходи, вжиті відповідно до цієї статті для подання конвенції компетентному органу або органам влади, повідомляючи йому всі відомості про цей орган або цих органах влади, що вважаються компетентними, і про прийняті ними рішення. Відповідно до п. 7 ст. 19 Статуту МОП, у відношенні рекомендації повинні бути здійснені аналогічні дії, але 3 метою розгляду можливості надання їй сили, шляхом прийняття закону або іншим способом.

3 метою сприяння однаковості у поданні інформації, що спрямовується урядами, щодо заходів, прийнятих на виконання зазначених вище положень, АР прийняла Меморандум про зобов'язання подання конвенцій і рекомендацій на розгляд компетентних органів влади (далі - Меморандум). Переглянутий Меморандум був прийнятий АР у березні 2005 року.

У Меморандумі відтворюються відповідні положення Статуту, і до нього включені витяги 3 доповідей Комітету експертів по застосуванню конвенцій і рекомендацій та Комітету конференції щодо застосування норм, з тим щоб роз'яснити цілі і вимоги, пропоновані до подання, характер цього зобов'язання і ряд запитів про інформацію. У ньому вказується також на необхідність проведення тристоронніх консультацій у зв'язку із зобов'язанням направляти національним парламентам акти, прийняті МКП.

Відповідно до Меморандуму, уряди зберігають за собою повну свободу дій щодо пропозиції будь-яких заходів, які вони можуть вважати належними відносно конвенцій і рекомендацій. Мета подання полягає у стимулюванні процесу прийняття швидкого та відповідального рішення кожною державою-членом по актами, прийнятими МКП. Зобов'язання направляти подання є основоположним елементом нормативної системи МОП. Мета цього зобов'язання полягала і продовжує полягати в тому, щоб акти, прийняті МКП, доводилися до відома широкої громадськості. 
Компетентний орган є органом, який, відповідно до Конституції кожної держави, має повноваження розробляти законодавство або вживати заходів іншого порядку в цілях застосування і дотримання конвенцій і рекомендацій. Зазвичай компетентний національний орган повинен бути законодавчим органом [13, с. 11]. Але з самого сенсу підп. 3 п. 5 ст. 19 Статуту МОП, де передбачено обов'язок держав-членів повідомляти Генеральному директору МОП «всі відомості про владу або влади, які вважає компетентними», випливає, що прерогатива визначення компетентної влади належить виключно самим державам.

Уряди мають повну свободу дій, у тому що стосується характеру пропозицій, які їм належить сформулювати при направленні актів компетентним органам, а також подальших заходів, які вони вважають доцільними для реалізації актів, прийнятих МКП. Зобов'язання представляти акти компетентним органам не має на увазі ніякого зобов'язання пропонувати ратифікацію конвенцій або прийняття рекомендацій.

Найважливішими аспектами, про які слід пам'ятати, є наступні: а) те, що під час або відразу після направлення конвенцій і рекомендацій законодавчим органам уряду повинні або вказати, які заходи могли б бути прийняті з метою реалізації цих актів, або запропонувати утриматися від будь яких дій, або ж відкласти ухвалення остаточного рішення; b) те, що повинна бути передбачена можливість поставити це питання на обговорення в законодавчому органі.

Тексти конвенцій і рекомендацій розсилаються урядам відразу після прийняття їх МКП у супроводі циркулярного листа, що містить нагадування про зобов'язання за поданням конвенцій i рекомендацій відповідно до статті 19 Статуту. До листа додається також Меморандум. Копії цих же документів направляються національним організаціям роботодавців і працівників. Після закінчення одного року після закриття сесії МКП, на якій були прийняті відповідні акти, всім урядам, які не подали необхідної інформації, направляється нагадування 3 додатком ще одного примірника Меморандуму [15]. Якщо по закінченні 18 місяців після закриття відповідної сесії МКП ця інформація не надійшла, то направляється повторне нагадування.

Важко виявити в законодавстві держав, тим більше на конституційному рівні, які-небудь спеціальні постанови, кореспондуючі цим міжнародним зобов'язанням. Одним 3 небагатьох прикладів може служити, мабуть, лише Конституція Італії, в ст.35 якої, зокрема, вказується, що «Республіка ... сприяє міжнародним угодам і міжнародним організаціям, що мають на меті закріпити й упорядкувати право на працю». Слід вважати, що при розширювальному тлумаченні цієї статті вона поширюється і на зазначені статутні зобов'язання, що випливають з участі Італії в МОП.

На практиці ж зобов'язання держав за поданням конвенцій і рекомендацій компетентним властям виконуються відповідно до загальних, як правило конституційними, положеннями про подання міжнародних договорів на розгляд відповідних органів. В одних країнах договори подаються на розгляд парламентів, національних асамблей, народних зборів і т.п. (Австралія, Канада, Конго, Коста-Ріка, Чехословаччина, Данія, Греція, Італія, Японія та ін.); в інших - главі держави (Бурунді, Еквадор, Гондурас та ін.); в третіх - уряду (Центральноафриканська Республіка, Куба, Маврикій, Нігерія, Папуа - Нова Гвінея та ін.).

Таким чином, виконання цього зобов'язання вельми важливо, оскільки воно веде до вирішення питання про ратифікацію або про іншу форму прийняття державами міжнародних конвенцій та рекомендацій про працю. Зобов'язання направляти акти компетентним органам сприяє зміцненню взаємин між МОП та цими органами і стимулює тристоронній діалог на національному рівні.

\section{Механізм оцінки стандартів на актуальність}

Механізм оцінки стандартів (далі МОС) є постійним механізмом, створеним Адміністративною радою у листопаді 2011 року для забезпечення того, щоб МОП мала чіткий, надійний та сучасний набір міжнародних трудових норм, який відповідає змінам у світі праці, з метою захисту робітників та з урахуванням потреб сталих підприємств. 32015 року в рамках МОС створена тристороння робоча група, яка складається з 32 членів та голови та збирається щорічно протягом одного тижня. Відповідно до пункту 9 ії технічного завдання, прийнятого в жовтні 2015 року, тристоронній робочій групі МОС надається доручення оцінити міжнародні стандарти праці з метою надання рекомендацій Адміністративній раді щодо: (а) стану досліджуваних стандартів, включаючи визначення таких статусів - сучасні стандарти, стандарти, які потребують перегляду, застарілі стандарти та можливі інші класифікації; (b) виявлення прогалин у охопленні конвенційним регулюванням, у тому числі визначення сфер, що потребують нових стандартів; (с) практичні та визначені у часі подальші дії щодо вдосконалення стандартів, за необхідності.

На сьогодні тристороння робоча група МПС провела п'ять засідань. Вона завершила експертизу 160 з 235 інструментів, перелічених у програмі ї роботи, включаючи огляд 68 морських інструмен- 
тів, які були передані Спеціальному тристоронньому комітету Конвенції про працю моряків 2006 року для експертизи [16]. Робоча група рекомендувала скасувати десять конвенцій та п'ять рекомендацій. Робоча група виявила прогалини в охопленні конвенційним регулюванням, що вимагають встановлення стандартів у п'яти сферах: виробнича практика, регулювання роботи з біологічними відходами, хімічними речовинами, безпека роботи з виробничими лініями, ергономіка праці та ручне перенесення і транспортування вантажів. Група також розробила спрощену класифікацію стандартів. Рекомендації тристоронньої робочої групи МОС були затверджені у повному обсязі Адміністративною радою, якою було підкреслено, що їі подальша діяльність є питанням інституційного пріоритету, стосується Організації, ії складових на глобальному та національному рівнях та Міжнародного бюро праці.

Впорядкування стандартів у конкретні категорії здійснюється відповідно до їх актуальності, застарілості чи потреби в перегляді. Класифікація стандартів має на меті інформування органів та складових частин МОП та керівництво діяльністю Міжнародного бюро праці та політикою розробки нормативного регулювання. Тристороння робоча група МОС прийняла трирівневу систему класифікації, яка відрізняє «сучасні» інструменти від тих, «які потребують подальших дій для забезпечення постійної та майбутньої актуальності» та «застарілих» інструментів.

Сучасні стандарти це ті, які визнані придатними за призначенням і тому можуть продовжувати просуватися Міжнародним бюро праці. Стандарти, які потребують подальших дій для забезпечення подальшої та майбутньої актуальності, є тими, які можуть бути не повністю актуальними в деяких аспектах, але залишаються актуальними в інших аспектах і тому не можуть бути класифіковані як застарілі [16]. Вони можуть включати інструменти, які перебувають у процесі повного або часткового перегляду, а також інструменти, що стосуються галузей соціальної та трудової політики, де необхідно розробити нові стандарти. Застарілі або застарілі стандарти це ті, які, здається, втратили своє призначення або вже не роблять корисного внеску в досягнення цілей Організації.

Найбільшу цікавість викликає юридична природа рішень МКП, згідно з яким діюча Конвенція визнається застарілою та вилучається із стандартів. Як результат, усі юридичні наслідки, що виникають у зв'язку 3 цією Конвенцією між Організацією та ії членами, остаточно усуваються, а самі держави, які ратифікували цю Конвенцію, більше не зобов'язані подавати звіти згідно зі статтею 22 Статуту МОП, і більше не можуть бути предметом до подань (стаття 24) або скарг (стаття 26) за недотримання; Наглядові органи МОП не зобов'язані перевіряти їі виконання, а Міжнародне бюро праці припиняє всі відповідні заходи, включаючи публікацію тексту Конвенції та офіційної інформації щодо їі ратифікаційного статусу. Однак скасування Конвенції не впливає на будь-яке національне законодавство, яке було прийняте з метою іії виконання, а також не заважає державі продовжувати застосовувати Конвенцію, якщо вона цього бажає.

Після набуття чинності в жовтні 2015 року поправки до Статуту МОП 1997 року, МКП наділена правом більшістю в дві третини голосів та за рекомендацією Адміністративної ради скасувати діючу Конвенцію, якщо виявиться, що вона втратила свою ціль або що вона більше не робить корисного внеску в досягнення цілей Організації (стаття 19 (9) Конституції). Термін «скасування» відноситься до чинних конвенцій, тоді як термін «відкликання» використовується для конвенцій, які ніколи не набирали чинності або більше не діють через денонсацію, та до рекомендацій [16].

Станом на вересень 2019 року МКП скасувала десять Конвенцій, включаючи Конвенції № 4 та 41, що забороняють нічну працю жінок у промисловості, Конвенція № 15 про мінімальний вік допуску підлітків на роботу в якості вантажників вугілля або кочегарів на флоті та Конвенції № 50, 64, 65, 86 та 104 щодо підбору корінних робітників на залежних територіях. Було встановлено, що всі ці Конвенції втратили своє призначення стосовно Організації або тому, що вони були замінені сучаснішими інструментами, або тому, що вони більше не відображають сучасну практику та концепції. Загалом скасованими або відкликаними є сімнадцять конвенцій МОП.

Таким чином, МОС є дієвим механізмом розвитку міжнародно-правового регулювання, який забезпечує актуальність конвенцій МОП. Крім того, наявність МОС сприяє забезпеченню спадковості у актах МОП та повинна не допускати появи колізій. Очевидно, що схожий механізм може діяти лише в рамках міжнародних організацій, під егідою яких розроблено суттєвий масив нормативного регулювання.

Механізм співробітництва між міжнародними організаціями у сфері становлення міжнародних трудових стандартів

Міжнародні організації, у багатьох відношеннях, діють чином, подібним на технічні департаменти національних урядів, але без центрального органу влади, який визначає завдання і може врегулювати конфлікти компетенції. Хоча спеціалізація міжнародних організацій дає істотні перева- 
ги, координація діяльності міжнародних організацій стає питанням надзвичайної важливості [17, с. 180]. У роботі міжнародних організацій існує значний ризик дублювання, упущень або навіть конфліктів. Тому координація необхідна на всіх рівнях. Вчений і колишній Генеральний директор МОП Уілфред Дженкс ще у 1958 р стверджував, що існує «конституційна відповідальність» зацікавлених міжнародних організацій за співпрацю в сприянні забезпеченню повної зайнятості [18, с. 229].

Стаття 12 Статуту МОП передбачає, що МОП співпрацює, в рамках цього Статуту, 3 усякою міжнародною організацією загального характеру, яка координує діяльність міжнародних публічно-правових організацій, що мають спеціалізовані завдання, і 3 міжнародними публічно-правовими організаціями, що мають спеціалізовані завдання в суміжних областях.

Здійснюючи зазначені у Статуті повноваження, МОП уклала договори, що визначають механізми співпраці, з наступними спеціалізованими установами ООН: ФАО (1947 р.), МАГАТЕ (1959 р.), МФСР (1978 р.), ММО (1959 р.), ЮНЕСКО (1947 р.), ЮНІДО (1991 р.), ВООЗ (1948 p), ВОІВ (1967 p.) i ЮНВТО (2008 p.).

Можна стверджувати, що між спеціалізованими установами ООН створено договірний механізм співробітництва з питань правового регулювання праці. Серцевиною цього механізму є МОП, яка уклала міжнародні договори $з$ дев'ятьма іншими спеціалізованими установами. Цей факт дозволяє зробити висновок, що питання регулювання праці входять до компетенції принаймні десяти спеціалізованих установ ООН. Сфери співробітництва визначено як представляючі взаємний інтерес, але чітко прописані лише в угоді між ЮНВТО та МОП. Сфера праці також може прописуватися в меморандумах про розуміння, але таких меморандумів на сьогодні укладено лише два.

Договори передбачають такі способи співпраці: 1) взаємне представництво у роботі конференцій і комітетів; 2) створення об'єднаних комітетів; 3) обмін інформацією та документами; 4) обмін співробітниками; 5) поширення і обмін статистичною інформацією. Договори можуть передбачати не усі форми співробітництва, а тільки деякі з них. Найбільш повні договори укладені $з$ тими міжнародними організаціями, з якими співробітництво здійснюється найбільш тісно.

Створення об'єднаних комітетів є найбільш ефективною формою співпраці між міжнародними організаціями, оскільки певна сфера життєдіяльності розглядається з різних сторін і 3 позицій діяльності декількох міжнародних організацій, які доповнюють один одного. Така форма співпраці може сприяти підвищенню ефективності міжнародного права.

Першим прикладом може служити об'єднаний комітет ФАО/СЕК/МОП з технологій, управління та підготовки кадрів у лісовому господарстві, який був створений у 1955 р. Комітет надає допомогу країнам у розробці іх лісового господарства в контексті сталого розвитку, сприяє міжнародному співробітництву в галузі технічних, економічних та організаційних аспектів управління лісами та методами ведення лісового господарства, підготовці працівників лісового сектора для лісозаготівельних і лісогосподарських операцій [19]. Підготовка працівників, та частина, яка безпосередньо відноситься до компетенції МОП, включає, окрім іншого, навчання персоналу прикладної ергономіці, безпеці та гігієні праці.

Чергові сесії об'єднаного Комітету звичайно проводяться раз на два роки. Об'єднаний комітет приймає програму дій на наступні 2-4 роки. Сесія зазвичай проводиться у поєднанні із семінаром по темі, що становить інтерес для приймаючої країни.

Більша частина роботи по здійсненню програми об'єднаного комітету лежить на керівному комітеті, який складається з голови, двох заступників голови, колишнього голови та п'яти координаторів, які розробляють програмні заходи, контролюють і сприяють їх здійсненню. Кожен координатор відповідає за свою сферу роботи, а ще один відповідає за роботу щодо країн $з$ перехідною економікою. Керівний комітет збирається щорічно.

За час свого існування цей об'єднаний комітет видав більше дев'яноста публікацій і спеціальних доповідей; кількість технічних документів, представлених на пленарних засіданнях та засіданнях дослідних групах, перевищила 500. Територія країн-учасниць простягається від Владивостока на сході до Ванкувера на Заході, від північних хвойних лісів до Середземного моря [20, с. 10].

3 моменту свого створення об'єднаний комітет займається питаннями запобігання нещасним випадкам під час лісових робіт. МОП також була стурбована великою аварійністю в лісовому господарстві. Питання, які були розглянуті в комітеті, включали вплив на здоров'я працівників вібрації і шуму від мотопил, реабілітацію літніх працівників після отриманих травм або хвороб, які обумовлені їх діяльністю. МОП надає підтримку шляхом надання стипендій та субсидій для участі в семінарах або навчальних курсах. Крім того, МОП взяла на себе завдання складання та видання різних навчальних посібників і керівництв.

У відповідності з договором між МОП та ВООЗ був створений об'єднаний комітет МОП/ВООЗ з гігієни праці. 3 питання ефективності роботи цього об'єднаного комітету, варто відзначити, що 
визначення мети гігієни праці, сформульоване в звіті першої сесії об'єднаного комітету у 1950 р і переглянуте за результатами роботи дванадцятій сесії у 1995 р, було прийнято Міжнародною комісією з гігієни праці і відображено в міжнародному кодексі для фахівців з гігієни праці. Також наголошується, що комітет вніс важливий внесок не тільки у визначення понять, але і в їх втіленні у національних та місцевих практиках [21, с. 16.3].

У роботі комітету основними напрямками діяльності МОП є створення міжнародних стандартів та правової основи для розвитку політик у галузі гігієни праці та відповідної інфраструктури на тристоронній основі (уряду, роботодавці і працівники) і практична підтримка в поліпшенні гігієни праці на робочих місцях, в той час як ВООЗ зосереджена на створенні наукової бази, методології, наданні технічної підтримки і на підготовці медичних і пов'язаних з цим трудових ресурсів для забезпечення гігієни праці.

Також об'єднані комітети можуть створюватися для контролю і кращого здійснення актів, прийнятих міжнародними організаціями. Рекомендація МОП/ЮНЕСКО про становище вчителів, прийнята у 1966 р, стала результатом тісної співпраці між МОП та ЮНЕСКО. Конференція ЮНЕСКО, на якій була прийнята рекомендація, також висловила сподівання, що тісна співпраця буде здійснюватися з метою здійснення зазначеної Рекомендації. Об'єднаний комітет експертів МОП/ЮНЕСКО щодо застосування Рекомендації про становище викладачів став результатом такої співпраці. Надалі мандат комітету був розширений у зв'язку з прийняттям Рекомендації ЮНЕСКО про статус викладацьких кадрів у вищій освіті у 1997 р. [170, с. 2]. Як правило, ЮНЕСКО займається головним чином питаннями освіти та його організації, в той час як діяльність МОП сконцентрована на відношенні між навчанням, з одного боку, і зайнятістю і працею, з іншого.

Механізм співпраці МОП та держав-членів у формі програм гідної праці для країни

Як зазначається у Резолюції про роль МОП у галузі технічного співробітництва від 15.06.2006 р., програми гідної праці для країни (далі - ПГПК), що розробляються на основі тристоронніх консультацій на національному рівні, слугують ключовим механізмом здійснення технічного співробітництва на рівні країни.

ПГПК вперше офіційно були запропоновані в якості програмної концепції у листопаді 2003 року і були включені до Програми діяльності МОП у 2004 році. АР неодноразово висловлювала свою повну підтримку розробці та проведенню послідовних програм МОП в країнах і, починаючи 3 2006-2007 рр., МБП перетворило ПГПК в основний механізм складання та проведення програм своєї діяльності в країнах. Досягнення цілей гідної праці на національному рівні стало одним із пріоритетних завдань Комітету з технічного співробітництва АР.

ПГПК переслідують дві основні мети. Вони сприяють гідній праці як ключовому компоненту стратегій національного розвитку. Гідна праця має стати метою національної політики урядів і соціальних партнерів, так само як і інших зацікавлених сторін на місцевому рівні. А також завдяки ПГПК статистичні дані, інструментарій та інформаційно-пропагандистська діяльність МОП можуть ефективно використовуватись тристоронніми учасниками на національному рівні.

ПГПК є комплексною основою, на якій будується співпраця МОП з кожною державою-членом. ПГПК є малим, але, можливо, вирішальним внеском МОП у досягнення національної мети, яку повинні ставити перед собою держави-члени, наприклад, проводячи національний план дій у сфері гідної праці.

ПГПК є інструментом складання програми, призначеним для активної децентралізації відповідальності при плануванні та проведенні послідовної та комплексної програми МОП щодо сприяння тристороннім учасникам в державах-членах. Центральними елементами цього процесу є трипартизм і соціальний діалог. Таким чином, МОП та ії національні тристоронні учасники несуть обопільну відповідальність за проведення ПГПК, а МБП несе всю відповідальність і зобов' язання за досягнення кінцевих результатів, передбачених у програмах. Перетворення цих результатів у конкретні практичні переваги вимагає активного залучення тристоронніх учасників та відповідних установ.

Методологія складання ПГПК являє собою шестиступеневий процес [22, с. 13]. Цими етапами є: 1) з'ясування становища країни; 2) погодження не більше трьох пріоритетів ПГПК з тристоронніми учасниками і з'ясування взаємозв'язків між поточною діяльністю МОП та відібраними пріоритетами; 3) визначення дворічних підсумків та результативності ПГПК спільно з тристоронніми учасниками; 4) планування здійснення; 5) управління здійсненням (директор місцевого бюро МОПє керуючим ПГПК і відповідає за досягнення узгоджених результатів; 6) моніторинг, звітність та оцінка. Процес носить повторний характер. Одночасно можуть проводитися заходи різних етапів.

У рамках МОП процес складання ПГПК проводиться за ініціативи місцевих бюро МОП. Для того, щоб посилити потенційні можливості польових структур, а також привести потреби у відпо- 
відність до узгоджених глобальних стратегій і результатів, необхідним є досвід технічних підрозділів штаб-квартири. Технічні підрозділи штаб-квартири повинні виділяти значну частину своїх ресурсів на обслуговування країн задля досягнення цілей ПГПК. Завдяки цьому підвищується можливість більшої ефективності наданих МБП послуг при тих же витратах.

У ПГПК включені конкретні напрями діяльності МБП в інтересах роботодавців та в інтересах працівників; при цьому наголос робиться на те, що процес зміцнення їхніх потенційних можливостей був орієнтований на пріоритети, враховані в ПГПК, з тим щоб МОП в цілому на рівні країни домагалася одних і тих же результатів.

Для того щоб забезпечити більш тісну інтеграцію технічного співробітництва з політичними рекомендаціями організації і більш тісно пов' язувати кошти з позабюджетних джерел з бюджетними коштами, важливо розуміти, що відповідність ПГПК стає критичним критерієм, завдяки якому можна оцінювати і відбирати пропозиції за програмою або проектом для внесення їх на затвердження донорів. 3 плином часу це повинно дозволити привести у відповідність весь портфель технічного співробітництва з пріоритетами ПГПК і дасть можливість МОП інвестувати основну частину ресурсів в ту чи іншу країну таким чином, щоб домагатися ключових узгоджених кінцевих результатів. Цей процес буде ще більш поглиблений завдяки проведенню аналізу інформації, що міститься в кінцевих результатах ПГПК на регіональному рівні та врахування їх у Програмі та бюджеті МОП в наступні дворічні періоди. Результати оцінок ПГПК переконливо свідчать про важливість розширення відповідальності самих країн за здійснення ПГПК за рахунок більш широкого співробітництва з тристоронніми учасниками. Незважаючи на те, що у всіх випадках тристоронні учасники залучалися до розробки ПГПК, контакти з партнерами протягом усього строку проведення цих програм інколи були слабкими.

ПГПК, як документи, не повинні бути довше 10 сторінок (4000-4500 слів) [22, с. 28]. Документ складається з чотирьох розділів, в рамках шести етапів, зазначених вище. Ці розділи полягають у наступному:

1. Дані по країні (2-5 сторінок). Тільки основні пункти, а не вичерпний аналіз. Включає в себе: основні тенденції і проблеми щодо гідної праці з будь-якими статистичними даними або даними 3 розбивкою за статтю; посилання на національні цілі в галузі розвитку, а також межі співробітництва в цій галузі, у тому числі наскрізні або першочергові напрями; пріоритети тристоронніх учасників; зобов' язання по ратифікованим конвенціям та можливі прогалини в імплементації; відповідні державні/донорські/інші програми; відповідні уроки, напрацьовані з минулої співпраці або попередніх ПГПК.

2. Пріоритети країнових політик (1 сторінка). Лише зазначення пріоритетів країнових програм (обгрунтування випливає з попереднього аналізу). Мають бути розроблені жорсткі варіанти, оскільки має значення обмежена кількість пріоритетів і адекватний діапазон - від одного до трьох пріоритетів максимум.

3. Результати країнових програм, показники і коротка стратегія (1-3 сторінки). Результати формулюються в стисло і точно. Для кожного результату є один або максимум три показники для вимірювання продуктивності. Кожен результат супроводжується заявою короткої стратегії, що вказує як буде продовжуватись робота. Можуть бути згадані критичні припущення і ризики. Проте, бажанішими є концентровані результати. Рамкова таблиця результатів має бути додана до загального документу ПГПК.

4. Планування впровадження, управління та оцінки (1 сторінка). Короткий опис механізмів управління для планування, моніторингу та звітності за ПГПК. Наприклад, налагодження національного тристороннього комітету, графіку ПГПК, будь-які заходи з оцінки і т.д. План моніторингу може бути доданий до ПГПК. План реалізації також має бути розробленим, але в якості внутрішнього інструменту управління; він не додається до загального документу ПГПК. Оновлення плану реалізації формує основу для періодичної, щонайменше річної, внутрішньої доповіді про виконання.

Станом на 30 серпня 2013 р. 59 ПГПК були діючими (з них 32 здійснювалися в Африці, 4 - в арабських державах, 10 - в Азійсько-Тихоокеанському регіоні, 6 - у Латинській Америці, 7 - у Свропі і Центральній Азії), 37 ПГПК перебували на стадії розробки проекту та консультацій 3 тристоронніми партнерами, а 13 ПГПК знаходилися на початковій стадії.

Таким чином, ПГПК є дієвим механізмом технічного співробітництва МОП та ії держав-членів. ПГПК розробляються, здійснюються і оцінюються у тісному контакті з тристоронніми партнерами, що забезпечує їх ефективність. Будучи невеликими за обсягом документами, вони дозволяють визначити проблемні місця (пріоритети) та шляхи вирішення цих проблем за допомогою МОП. Для кращого розуміння ПГПК в подальшому доцільним видається порівняльно-правовий аналіз таких програм у різних державах. 
тже, в рамках МОП визначено шість аспектів, які впливають на ії ефективність. Робота на основі принципу трипартизму та механізм оцінки стандартів на актуальність є унікальними характеристиками МОП. Ці аспекти можуть і навіть повинні бути запозичені іншими міжнародними організаціями у свою діяльність. Механізм подання компетентним органам держави текстів нових, тобто щойно прийнятих, міжнародно-правових актів для вирішення питання можливості їхньої ратифікації не є характерною ознакою лише МОП, але в рамках саме цієї міжнародної організації даний механізм прописано найдетальніше, що пов'язано, в тому числі, із залученням до нього недержавних учасників соціального діалогу. Механізм співробітництва між міжнародними організаціями на прикладі МОП являє собою вдалий приклад делегування вирішення профільних питань спеціалізованим міжнародним організаціям, що дозволяє забезпечити їх найбільш ефективне вирішення. Контрольний же механізм із оцінки рівня дотримання державами міжнародних трудових стандартів та надання їм рекомендацій, в тому числі і через механізм співпраці МОП та держав-членів у формі програм гідної праці для країни, вдало демонструє, що головна мета міжнародного права, принаймні в галузі міжнародного права прав людини, полягає не у покаранні держав, що його не виконують, а у з'ясуванні причин такого невиконання і доведенні необхідності та корисності його дотримання та слідуванню йому.

1. Hetherington H.J.W. International Labour Legislation / Hector James Wright Hetherington. London: Methuen \& Co., 1920. - 195 p.

2. Rosa A.-M. L'expérience singulière du tripartisme au sein de l'Organisation internationale du Travail / Anne-Marie la Rosa, Isabelle Duplessis // La démocratisation du système des Nations Unies / dir. Rostane Mehdi. - Paris: Editions A. Pédone, 2001. - P. 123-139.

3. Constitution of the International Labour Organisation // Constitution of the International Labour Organisation and Selected Texts. - Geneva: International Labour Office, 2010. - P. 3-24.

4. Роль Комитета по проверке полномочий. Третий пункт повестки дня [Электронный ресурс] // LILS. - Женева, март 2003 г. - Режим доступа: http://www.ilo.org/public/russian/standards/ relm/gb/docs/gb286/pdf/lils-3.pdf.

5. Dahan Y. Shared Responsibility and the International Labour Organization / Yossi Dahan, Hanna Lerner, Faina Milman-Sivan / / Michigan Journal of International Law. - 2013. - Vol. 34:4. - P. 675-743.

6. Osieke E. Constitutional Law and Practice in the International Labour Organisation / Ebere Osieke. - Dordrecht: Martinus Nijhoff Publishers, 1985. - 266 p.

7. Tikriti A.-K. Tripartism and the International Labour Organisation: a study of the legal concept : its origins, function, and evolution in the law of nations / Abdul-Karim Tikriti. - Stockholm: Almqvist \& Wiksell International, 1982. - 417 p.

8. Fourth item on the agenda: Decent work for domestic workers. Report of the Committee on Domestic Workers. Provisional Record. 100th Session, Geneva. - №15, 15 June 2011 // [Електронний ресурс]. - Режим доступу: http://www.ilo.org/wcmsp5/groups/public/@ed_norm/@relconf/documents/ meetingdocument/wcms_157696.pdf.

9. Valticos N. International labour standards and human rights: Approaching the year 2000 / Nicholas Valticos // International Labour Review. - 1998. - Vol. 137. - № 2. - P. 135-147.

10. 10. Стаценко В. Г. Конвенции Международной организации труда: механизмы имплементации и контроля за применением / Владимир Григорьевич Стаценко // Белорусский журнал международного права и международных отношений. - 2002. - № 2. - С. 18-22.

11. Leary V. International Labour Conventions and National Law: The Effectiveness of the Automatic Incorporation of Treaties in National Legal Systems / Virginia A. Leary. - The Hague: Martinus Nijhoff Publishers, 1982. - $191 \mathrm{p}$.

12. Boivin I. The Committee of Experts on the Application of Conventions and Recommendations: Progress achieved in national labour legislation / Isabelle Boivin, Alberto Odero // International Labour Review. - 2006. - Vol. 145. - No. 3. - P. 207-220.

13. Руководство по процедурам, касающимся международных конвенций и рекомендаций о труде // Департамент международных трудовых норм Международного бюро труда. - Женева: Международное бюро труда, 2012. - 75 с.

14. Аметистов Э. М. Факторы имплементации норм международного права : на примере международных норм о труде : автореф. дисс. на соискание уч. степени доктора юр. наук : спец. 12.00 .10 «Международное право» /Э.М. Аметистов. - М.,1984. - 52 с. 
15. Memorandum Concerning the Obligation to Submit Conventions and Recommendations to the Competent Authorities [Електронний ресурс]. - Документ МОП. - GB.292/10(Rev.) - Режим доступу: http://www.ilo.org/wcmsp5/groups/public/@ed_norm/@normes/documents/questionnaire/ wcms_087324.pdf.

16. Glossary of terms associated with international labour standards. Fifth Meeting of the Srm Tripartite Working Group (23-27 September 2019) [Електронний pecypc]. - Режим доступу: https:/ /www.ilo.org/ wcmsp5/groups/public/---ed_norm/---normes/documents/genericdocument/wcms_715398.pdf.

17. Charnovitz S. The International Labour Organization in its Second Century / Steve Charnovitz // Max Planck Yearbook of United Nations Law. - 2000. - Vol. 4. - P. 147-184.

18. Jenks W.C. The Common Law of Mankind / Wilfred C. Jenks. - New York: F.A. Praeger, 1958. $-456 \mathrm{p}$.

19. Joint FAO/ECE/ILO Committee on Forest Technology, Management and Training. Facts about the Joint Committee [Електронний ресурс]. - Режим доступу: http://www.unece.org/fileadmin/DAM/ timber/joint-committee/facts.htm.

20. Peck T.J. The Joint FAO/ECE/ILO Committee : Fifty Years of International Co-operation in Forestry - The Evolution and Achievements of the Joint FAO/ECE/ILO Committee on Forest Technology, Management and Trainining from 1954 to 2004 / T.J. Peck, E.G. Richards // ILO Sectoral Activities Department, Working Paper 220. - Geneva: International Labour Office. 2004. - 81 p.

21. Rantanen J. Standards, Principles and Approaches in Occupational Health Services / Jorma Rantanen, Igor A. Fedotov // Encyclopaedia of Occupational Health and Safety // ed. Jeanne Mager Stellman. - 4th ed. - Vol. I. - Geneva: International Labour Office, 1998. - P. 16.2-16.18.

22. ILO Decent Work Country Programmes, A Guidebook. - Version 3. -Geneva: International Labour Office, 2011. - 40 p.

\section{Summary}

The article focuses on the ILO's centennial and explores aspects that determine its effectiveness: 1) activity based on the tripartism principle; 2) specific control mechanism for assessing and providing recommendations to Member States on compliance with international labour standards; 3) submitting mechanism to the competent State's authorities of the newly adopted international labour standards texts in order to study the possibility of its ratification; 4) standards review mechanism; 5) cooperation mechanism between international organizations in the field of international labour standards; 6) cooperation mechanism between the ILO and its Member States in the form of decent work country programmes. These driving forces were considered as the ILO's greatest jewels and its "gift" to international law. However, the list of mentioned above aspects is not exhaustive.

Tripartism allows to take into account the positions and proposals of all interested parties starting from the very beginning of the convention and the accompanying recommendation construction, while usually non-state actors are allowed to participate at this process only at the stage of preparation for ratification or even afterwards. As a result the international legal regulation implemented by the ILO effectiveness increases dramatically.

The implementation of international legal obligations in the field of labour relations is extremely complex and requires considerable efforts. Although the problematic aspects of the ILO Conventions implementation remain, the implementation process, which accordingly leads to a reform process, is ongoing. The impact of the ILO on national labour laws reform is through the conclusions submission to the ILO States Parties. These conclusions usually include recommendations on the proper application of ratified conventions. The Committee of Experts plays an important role in this process, even though it has quite softly legal mechanisms of influence, as states, including Ukraine, try to be in line with the conclusions they are given.

Submitting mechanism to the competent State's authorities of the newly adopted international labour standards texts in order to study the possibility of its ratification is quite important as it leads to the ratification or other form of adoption by States of international labour conventions and recommendations. The obligation to submit acts to the competent authorities helps to strengthen the relationship between the ILO and these bodies and promotes tripartite dialogue at national level.

Standards review mechanism is an effective mechanism for the development of international legal regulation, which ensures the relevance of ILO conventions. In addition, the application of this mechanism contributes to the continuity of the ILO acts and should not allow collisions to occur. Obviously, a similar mechanism applies only within the framework of international organizations, under the auspices of which a substantial array of regulatory regulation developed. 
A contractual cooperation mechanism on labour issues legal regulation has been established between the UN specialized agencies. The ILO is the core element of this mechanism, since it has concluded international agreements with nine other specialized agencies. The treaties provide the following ways of cooperation: 1) mutual representation at conferences and committees; 2) establishment of joint committees; 3) exchange of information and documents; 4) exchange of employees; 5) dissemination and exchange of statistical information.

The Decent work country programme (DWCP) is an effective mechanism for technical cooperation between the ILO and its Member States. DWCPs are developed, implemented and evaluated in close contact with tripartite partners to ensure their effectiveness. As documents are small, they allow you to identify areas of concern (priorities) and ways to address them through the ILO. For a better understanding of the DWCP, a comparative legal analysis of such programs in different countries seems appropriate.

Thus within the ILO six aspects that affect its effectiveness were mentioned. Activity based on the tripartism principle and the standards review mechanism are unique characteristics of the ILO. These aspects can and even should be applied by other international organizations in their activities. The submitting mechanism to the competent State's authorities of the newly adopted international labour standards texts in order to study the possibility of its ratification is not a characteristic feature of the ILO alone, but within this international organization, this mechanism is prescribed in the most detailed way, including involving of social dialogue non-state actors. The ILO cooperation mechanism with otheer international organizations is a good example of specialized issues delegation to specialized international organizations, enabling them to provide the most effective solution. The specific control mechanism for assessing and providing recommendations to Member States on compliance with international labour standards, including cooperation mechanism between the ILO and its Member States in the form of decent work country programmes, demonstrates the main objective of international law. At least international human rights law is not to hold states that fail to comply with it to account, but to find out the reasons for such non-compliance and to prove the necessity and usefulness of its observance and compliance with it. 